\title{
Ethiopian Cinema: The Socio-economic and Political Impacts of Imperial Era on the Development of Screen Media ${ }^{1}$
}

\author{
Aboneh Ashagrie \\ Addis Ababa University, Addis Ababa, Ethiopia
}

\begin{abstract}
Ethiopia that had been at the high-up as one of the few world powers in the 1st and early centuries of the 2nd millennium, and later to descend to poverty line to the extent of being synonym for famine and degradation in an English dictionary, is currently on the verge of socio-economic renaissance. Likewise, the country that experienced film viewing in the very early years of the development of world cinema for more than hundred years had eventually lagged behind those African countries exposed to cinematic arts a few decades ago; but now relatively ascending to its historical status. These days, over hundred films are produced on annual bases in Ethiopia. Nevertheless, articles, books, and encyclopedias written on African and world cinema do not as such include the Ethiopian account, hence adversely affecting the wholeness of universal knowledge. This research thus attempts to investigate the socio-economic and political impacts that governed the development of the Ethiopian screen media during imperial era (1897-1974). The inconsistency in the development of Ethiopian cinema will be analyzed and demonstrated in conjunction with the socio-economic and political features in the era of Emperor Menelik II, Lij Iyasu, Empress Zewditu, and Emperor Haile Sellassie. The study will portray the strong link between Cinema and mode of productions that would be of a scholastic benefit to the Ethiopian and the international academia. The article hopefully, will contribute to the historiography and completeness of African screen median in particular, and world cinema in general.
\end{abstract}

Keywords: Ethiopia, cinema, development, socio-economic and political impacts, historiography

\section{Introduction}

Ethiopia had been one of very few countries that marked highest stage of ancient civilization beginning with the Axumite Kingdome as early as the first millennium. The civilization continued by adopting Coptic Christian civilization in the 4th Century AD, which was extended by the Zagwe Dynasty up until the 2nd century of the second millennium. The sustainability of that civilization was hampered by successive wars waged by followers of Judaism and the Oromo movement, and later in 1530s by Islam expansionist who gained control of most of the territory for about 14 years. The inter-regional powers struggles that prevailed mostly in the form of ethnic strive up until the end of 1880 s had also a serious adverse effect on the cultural development.

\footnotetext{
Aboneh Ashagrie, BA in Theatre Arts, Associate Professor, School of Theatre Arts, Addis Ababa University.

Correspondence concerning this article should be addressed to Aboneh Ashagrie.

This article is dedicated in Honor of Professor Richard Pankhurst, who committed his life to writing Ethiopian history and culture. Professor Richard Pankhurst passed away on 16 February 2017, and his body rested at the Addis Ababa Trinity Cathedral on 21 February 2017 with national hero's last farewell ceremony.

1 "African screen media" (Dovey, 2009) is coined to denote the "divers format" (video, television, new media) in which films are made.
} 
It was after many centuries that a new form of civilization began to immerge under the Emperorship of Menelik II in 1890s. The uprooting civilization was indeed the western capitalist civilization that was governed both by the international socio-economic and political reality and the decadence of the old feudal mode of production. This led to the introduction of cinematic arts in Ethiopia 1897. Since then, Ethiopia has passed through various stages of film exhibition and production. This paper hence, would attempt to portray the socio-economic and political factors that have adversely and/or favorably affected the development of screen media in Ethiopia for over a century. For the sake of convenience, the study will observe the developments in line with the features of the successive Ethiopian four states: the region of Emperor Menelik II, Lij Iyasu, Empress Zewditu, and Emperor Haile Sellasie.

\section{Emperor Menelik II and Film}

\section{Legacy of the Victory of Adwa for the Advent of Cinema}

1895, the year that the Lumiere Brothers invented cinematography (Ekwuazi, 1991) coincided with the period that Ethiopian people fought and defeated the Italian colonial army at the battle of Adwa during the first world War.

The victory of Adwa that "sent shock wave throughout Europe," in 1896 (Adejumobi, 2007, p. 30) and that brought Ethiopia to the attention of the world had forced international politicians and business men to reassess their positions with Ethiopia. As a result, the rival powers in Africa, particularly France, Great Britain, and Germany confronted each other to win diplomatic relation with Emperor Menelik II. Foreigners, in private or official capacity, flocked to Addis Ababa to seek favors in order to promote their interest (Bahru, 1991, pp. 97-101). Emperor Menelik II on the other hand exploited the political environment in order to modernize Ethiopia by increasing foreign contacts and listening carefully to the advice of each foreign ambassador, advisor, and agent, who perpetually endeavored to promote the influence and advantage of his own government (Adejumobi, 2007, pp. 54-55). These are some of the major factors that led to the advent of cinema in Ethiopia in 1897, just three years after the introduction of the first moving picture in the world.

The most illustrative account in regards the beginning of cinematic experience in Ethiopia is read in $A l$ tempo di Menelik (Pariset, 1937) ${ }^{2}$. It was hand written by Stevenin who lived in Ethiopia during the time of Emporer Menelik II, and was published after three decades by Dante Pariset, who received the script from the author. According to Stevenin (Pariset, 1937, pp. 152-156), a certain Greek came to him and asked if an electric generator was available to introduce a film show. Stevenin responded that the Emperor had one but was unable to use it. With that initiative, Stevenin approached the Emperor and received the engine for a tryout. The gas was full tank. With the help of friends, the generator worked and illuminated the campus in the evening. The Greek went to him again and expressed his interest to show a film with it. Stevenin then approached Emperor Menelik II through Signor Jauma, an assistant advisor to the Emperor. Pawlos Ngongo (1984, p. 337) paints the then conversational atmosphere as follows:

When the Emperor heard the word cinema, he asked what cinema is. Stevenin gave a detailed explanation, and told the Emperor that he had wanted to bring it to Ethiopia, but scared that the clergy would oppose him. The Emperor retorted, "I don't care if the clergy opposes it. Forget the clergy; I want to see this thing. Bring it soon."

\footnotetext{
2 Parts of the book "PREMESSA" (5-8), and Capterxx III "TELEFONO, LUCE ELETTRICA, CINEMA" (152-156) have been translated from Italian to English for my consumption by Isabel Boavida, a colleague teaching at Department of Foreign Languages at the Addis Ababa University; and by Dr. Haile Muluqen, assistant Professor of History at the Mekele University.
} 
After permission was granted, Stevenin brought a 40-65 watt projector and an electrician from Europe. He also drafted a business proposal for the Greek to finance the project and to select a film that fitted the aristocracy and the clergy. Accordingly, passion of Jesus Christ was screened, with a cut on the episode of Christ being challenged by Satan (Pariset, 1937, pp. 152-156). Stevenin seems to have been wise to carefully select scriptural film that went in accordance with the interest of members of the Christian state and the powerful Coptic Church. He might have also proofed himself right when he observed the nobility and the clergy flung themselves on to the floor bowing in respect to the cinematic image of Jesus Christ walking on the sea. The response of the nobility and the clergy during the film run was live and participatory, with chaotic verbal reaction and hot discussion which was halted to silence by the order of the Emperor and Ras Mekonnen (Pariset, 1937, pp. 152-156).

After the film show in the palace on Miyazia 1, 1889 E.C [April 9, 1897], the Emperor, dumfounded by the new technology said to Ras Mekonnen (Father of Emperor Haile Sellassie) "It is surprising! There is nothing that foreigners cannot create; they have created everything, save the soul of human being" (Pawlos Ngongo, 1984, p. 337).

After such recognition was given to cinema by the Emperor, it did not take much time to start a movie business in Addis Ababa. "The first attempt at establishing a cinema was made in 1898 by a French man from Algeria" (Pankhurst, 1968, p. 710), in the first cinema theater built "attached to Hotel de France" (Gerard, 1971, p. 412). This may establish a fact that Ethiopia is the 1st country in Sub-Sahara Africa to exercise film viewing, for it was late "between 1898-1902" (Petty, 2007, p. 49) that cinema was introduced in South Africa.

\section{Cinema Ex-communicated: Contradiction Between the Old and the New Systems}

The contradiction between the then collapsing feudalism and the budding Capitalist system was manifested in the early stage of the development of cinema in Ethiopia. The aristocracy and clergy who were the most conservative power of the feudal system resisted Emperor Menelik's endeavor of Ethiopian modernization in every aspects. The aristocracy and clergy associated secular education with heresy, and science with the work of the Devil (Gebru Tareqe, 2009, p. 16). Likewise, cinema was not welcomed by this category of the ruling class, and it was believed that the moving images in the dark hall were either sorcery or a product of Satan. The society which grew up listening to the belief that Satan could appear in darkness through sorcery, had to take the words of the clergy for granted when saw intangible silent images in the "black air". No wonder that the priesthood and the devoted Coptic society who saw the mysterious anecdotes which was not in the hall before the light off, mistook the movie images for devils reality to consider cinema as the "House of Satan" (Pankhurst, 1968, p. 722). Hence, the movie theatre retained the name Ye SeitanBêt [House of Satan] and then ex-communicated officially by the clergy.

In spite of this, the owner of the movie theatre, in order to attract people to the new business had to let the public see religious movies for free at the initial period. Regardless of the clergies' agitation against film exhibitions, the pubic rather became enthusiastic to witness what had been preached as a Satanic magic.

When the number of cinema viewers grew, entrance fee was then introduced. According to Ross (1969, p. 11), "A seat on the front side of the screen cost a quarter of a Maria Theresa dollar. The last well-to-do had the unique opportunity to sit 'backstage'. A 'seat' on the wrong side of the screen... costone Mahalek 
(one-sixteenth of a Maria Theresa dollar), that was "to sit on stone"” (Addis Ababa Millennium, 2007, p. 40). The entrance fee however was a surprise to the public, and an Amharic poem was coined in protest against the payment (Tesfaye Lema, 1985, p. 19):

It [the film] does not go to the belly; neither eaten, nor drunk!

How on earth one pays merely for what the eye see!

Oh! What a surprising era!

Eventually, the excommunication became successful in halting the people temporarily from going to $Y e$ Seitan Bête. Expatriate business men, particularly the Arabs and few Ethiopian Muslims however had made an attempt to challenge the excommunication in order to save the box-office from failure by sponsoring night screenings to their families where most of the wives watched the film, covering halve of their face in disguise (EFC, 1988, p. 9). At last the movie theatre "went bankrupt... and [the owner] sold his apparatus to the Italian Minister, Ciccodicola" (Pankhurst, 1968, p. 710). It was a paradox that Ciccodicola, a diplomat of a country that had waged war and suffered a defeat at Adwa two years earlier, and that had been planning to reinvade Ethiopia after four decades, presented the film projector as a gift to Emperor Menelik II. The Emperor then used the projector to change the negative attitude of the aristocracy and the clergy by viewing successively religious films in the palace. When Emperor Menelik II realized that the opposition had toned dawn, he encouraged a certain Baicovich brothers to go into film business. The brothers started showing movies to the public in a newly built movie theatre in 1908/09 [1901 E.C]. The business run in Addis Ababa smoothly for a year and the cinema was closed when the projector faced technical problem. Film screening however continued in Diredawa, eastern part of Ethiopia where a good number of foreigners resided as business men (Pawlos Ngongo, 1984, p. 337).

\section{An Alternative: French's Shift to Film Production}

After the abortion of film business in Addis Ababa, the French, in order to sustain their cultural influence in Ethiopia shifted to safest alternative, i.e. from film screening to documentary production that focused mostly on palace anecdotes. "In 1909, a Frenchman named Charles Martel went to Ethiopia with a camera provided by Lumiere brothers. He filmed Balcha (the Ethiopia army general) in Harar, the paralyzed Menelik II in Addis Ababa as well as scenes of solders, slaves and dancers" (Prouty, 1994, p. 244). This film, L'Abyssinie au temps de Menelik [Abyssinia during Menelik], a 24 minutes documentary, as the first film ever taken in Ethiopia, marks a turning point in the history of Ethiopian film.

\section{Cinema and the Reign of Lej Iyasu: International Boycott (1911-1916)}

In the following six years, the French did not attempt any film activity due to political opposition against the reign of Lij Iyasu who succeeded Emperor Menelik II from 1911-1916. The French and its allies (Britain and Italy) were not comfortable with Lij Iyasu's intent towards maintaining a stronger diplomatic relation with Central Powers, particularly with Germany and Turkey. The Allies felt that Iyasu was a treat to them, and should be eliminated forthwith. The Allies, in collaboration with Ras Teferi Mekonnen (the future Emperor Haile Sellassie) overthrew Lij Iyasu. In 1916, Zewditu as the Empress and Teferi Mekonnen as regent and heir to the throne took over the state power. The change in political arena revived the Allies' diplomatic relation as early as the coronation day in February, 1917 (Bahiru, 2007, pp. 127-135). 


\section{Film During Empress Zewditu (1916-1930)}

\section{Revival of French Influence: Documentary Productions}

The French, due to the partisanship of RasTeferi, immediately seized the new opportunity to return back to film activity by producing Addis Ababa (7') and Fetes du couronnementde la ReineZaoditou (13') [Coronation of Empress Zewditu] in 1917. The film was made by Amedee Eywinger, and as the title indicates documented the coronation ceremony including the representation of French, Italy, and Russia. Three years later, Edmond AM Famechon produced La Mission Charles Michel-Cote. Ethiopie-Soudan (29') [The Visit of Charles Michel-Cote. Ethiopia-Soudan]. In 1928, Lenouveaunigus (1'46) [The New King] which illustrated the coronation of TeferiMekonen as Nigus [king] was produced.

\section{The 1st Documentary Film by an Ethiopian; the 1st Sub-Sahara African Docufilm by a Native}

A new development of Ethiopian cinematic art was marked in 1920 when Tedla Tesemma (AACCA, 2007, p. 40) immerged as the first Ethiopian cinematographer by producing a $16 \mathrm{~mm}$ black and white-silent documentary film based on the 1917 coronation of Empress Zewditu, in which Crown Prince Teferi Mekonnen appears sitting more vividly in front of the tent where the Empress is seen in veil. The production of the documentary might have been initiated and commissioned by Crow Prince Teferi when the power struggle between Empress Zewditu's supporters and the Crow Prince had reached its climax. Crown Prince Teferi who had immerged as the most powerful figure in the government was suspected by the aristocracy for crawling fast to overthrow Empress Zewditu, in the same manner, he had ousted Lej Iyasus. Teferi might have intended to use the documentary film for tactical reason; just to view him as subordinate and loyal, hence erasing the suspicion that he would snatch the throne from her. This point calls again for historiography of African and world cinema. The fact that some scholars (Dovey, 2009, p. 6) regard La Mort de Rasalama (Roberono, Madagascar, p. 1947) as the first documentary film by black Africa; and Petty's (2007, p. 49) assertion that the 1955 Senegalese production Afrique-str-Seine (Africa on the Seine) is "the first film shot by a black African" should be reconsidered for the mere reason that it was the Coronation of Empress Zewditu (Tedla Tesemma, Addis Ababa, p. 1920), produced in Ethiopia that preceded La Mort de Rasalam by 27 years; and Afrique-str-Seine by 35 years.

\section{Expansion of Cinema With the Growing Capitalism}

In the 1920s, Ethiopia advanced with Capitalist system that relatively created conducive condition for cinema development. Marcus $(1994,125)$ provides the socio-economic picture of the 20s as follows:

... the capital boom. The money supply grew sharply, imports and exports doubled, and another thirty-five thousand people came to seek work. Many were employed ...; others became day laborers... The aristocracy invested in commerce and real estate in the capital, where property values soared. They and an emergent commercial and bureaucratic bourgeoisie began building stone-walled, tin-roofed, and square modern houses that they furnished with locally made or imported European-style furniture. The wealthy among them and many Europeans purchased automobiles, some three hundred of which circulated in the city in 1927, symbolizing Ethiopia's increasing involvement in the world economy.

Ethiopia's involvement in the world economy, indeed had laid a fertile ground for increasing involvement in the world culture as manifested in film business. The influence of French in the Ethiopian school curriculum, the return of educated Ethiopians from abroad, and the growing number of workers and foreigners in Addis Ababa seemed to have encouraged French and Greek expatriate counterpart as well as a local person to go seriously into film business. In 1923, Ye Seitan Bet was reinstated by a French man who adjacent to it run Hotel 
Terrance $^{3}$ sometimes on credit basis. Following that, more than four movie theatres were constructed at Arada, the "down town" of Addis Ababa successively within a short period in a radius of less than a kilo meter. In 1927, Philis (a Greek) constructed Cinema Ethiopia about where the Ethiopian Airlines office is now. Then, across the street from it where the Ethiopian Electric Power Head Quarter building now is, a French man Gleyze opened the capital's first "talkie" cinema just prior to the war (Ross, 1969, pp. 11-13).

In the decade, Ethiopia's subject matter also begun to attract the attention of American, British, and German film makers. Accordingly, Expeditions by American film producers to Africa have included footage taken in Ethiopia. The first expedition headed by Edward Salisbury produced The Lost Empire in 1923, and the film was screened in New York in 1929. Ras Teferi Mekonenn, took the filming expedition to his political advantage to strengthen diplomatic relation with the USA. The second "Abyssinian Expedition", headed by Daniel Davenport, sponsored by the Daily-News and the Field Museum of Natural History of Chicago has produced Jango in 1926, which is preserved at the Museum of Natural History in New York. Ethiopia (60') portraying Axum, Blue Nile, Daga, Deq, Gondar, Lake Tana, Lalibela, Tissisat Falls was produced at that time, and preserved at the New York's Natural History Museum. The British Pathe produced In Far off Abyssinia in 1927 (www.britishpathe.com). In the same year, the German produce Dime, an ethnographic film which pictured the mining of iron in Ethiopia (Prouty, 1994, p. 244).

\section{Cinema in the Era of Emperor Haile Sellassie (1930-1974)}

\section{Emperor's Early Attachment to Film}

Though Zewditu was the Empress from 1916 to 1930, it was Ras Teferi who as the most influential regent had created conducive atmosphere for the development of cinema in Ethiopia in those years. Teferi, after his coronation as Emperor Haile Sellassie had continued to do so to the extent of securing film projectors in the throne room. In relation to this, Farago (1935, pp. 24-77) who visited Ethiopia and was received by the Emperor in early 1930s writes:

He [film projector technician] led me next door and showed me two up-date sound film apparatuses which projected into the throne room. I was presented a little later, and then the Emperor showed us, first of all, scenes of native life and then a French talkie comedy. Both pictures and sounds were first class. This will always be my most interesting visit to the cinema.

The film technician was Georg Derniguliyan, who learned film projection in 1929/30 from Chombe, then a medical doctor and researcher at Pastor Institute (EFC, 1988, p. 12). It was no surprise that the Emperor as fluent French speaker (Getahun, 2007, p. 35) and friend to France favored French films and film makers. Farago (1935, pp. 24-77) also remembers that a documentary film about the country had been made by a Swiss flyer with the personal help of Haile Sellassie, but in the studio it was given an anti-Abyssinian bias. He further notes the discontent of the Emperor he witnessed in regard the biased films about Ethiopia:

I am often reproached in Europe for allowing my country to remain uncivilized, but those people accuse me do not know Abyssinia, and allow themselves to be misled by biased books and bad films, many which are made not in Ethiopia at all but in the brothels in Djibouti.

\footnotetext{
${ }^{3}$ Some people also used to call it Ye Musie Terass Cinema [Mr. Terrace Cinema ] and Cinema Terrasse (Aboneh, 2012, 106). But the name Terrace is not actually used as a French name; and therefore the cinema might have been named "Terrance Cinema" by the owner to indicate the topography of the vicinity where the hall was built. The cinema also played another historical role by hosting the first drama production in Ethiopia in 1920/1921(Aboneh 2012, 1-2). The new art form, unlike the cinema was welcomed by the public though immediately band by Empress Zewditu, accused for being critical to the throne.
} 
From these, it is noted that foreigners some times were playing double standard by making positive and negative films about Ethiopia. The British has also produced The 16 years old prince of Ethiopia (1932), and HIM Haile Sellassie I Coronation (1930).

On eve of Italian invasion, new occurrences regarding cinema were observed. "Tax on entertainment was embodied in a decree of August 5, 1932 for the regulation of...Cinemas..." (Pankhurst, 1968, p. 533). In 1934, Eda (French) opened Cinema Peroche in Arad to the eastern side where the present Cinema Empire is found; George Ties (Greek) opened Cinema Mancini right in front of the present Cinema Ethiopia; Asterio Papatakis, a Greek business man who owned Majestic Hotel also built Cinema Majestic adjacent to it, where the British Council is currently erected (EFC, 1988, pp. 5-14; Arefayne, 2014, p. 2).

\section{Cinema During the Italian Invasion (1936-1941)}

When Fascists Italy invaded Ethiopia during the 2nd World War, Arada was set on fire in May 1936, (Campbell, 2010, pp. 43-47) leading to the destruction of movie theaters in Addis Ababa. Fascists Italy, after occupying Addis Ababa, soon focused on renovating and constructing new cinemas with European standard to entertain its army and to disseminate Fascist propaganda onto the public as well. As a result, seven movie theatres were opened, out of which six were located at Arada (then baptized by Italian name as Piazza). The building which had served as the city post office before Italian invasion was reconstructed as the prestigious Cinema Italia (currently cinema Ethiopia). The location was immediately east of Casa Littoria which was the principal Fascist assembly hall and meeting place (Campbell, 2010, pp. 62-101). Cinema Mancini was given the name Cinema Roma. Cinema Marconi was constructed at the place where the present Arada Mall is constructed. Cinema Peroche was substituted by Cinema Empero and it was mainly for the Fascist Youth members. The Fascist also extended movie centers to other geographical directions, just one and two kilometers away from Arada/Piazza. Cinema Kamboni was built in the east at Arat Kilo where the Addis Ababa University Science Faculty is seen nowadays, and it is also named Cinema "Cinque Majo" to remained Italians of their entry in to Addis Ababa" (Lentakis, 2005, p. 57). Cinema Dapo Lavoro was built south from Arada/Piazza near the present day Mexico Square where Tegbare-id Technical School is erected. Ras Hailu, governor of Gojam, and an Ethiopian aristocrat business man who was the most serious rival of Emperor Haile Sellassie economically and politically (Bahru, 2007, p. 98), and who collaborated with Italian Fascism opened Cinema Ras Hailu in 1938 in the western chubby segregated Markato. He was the first Ethiopian to own movie theatre in the history of cinema. An ambitious construction had also been attempted for the expansion of Cinema Marconi in the south, but left incomplete due to the expulsion of the Fascists from Ethiopia. Movie halls were also constructed in provincial towns like Dessie, Diredawa, Gonder, and Jimma, and according to Ben-Ghiat (2003, p. 55) "by March 1939, there were forty cinemas in Ethiopia with a total of 30,000 seats; by 1940, this number had grown to fifty-five cinemas with 60,000 posts".

These movie theaters, productions of Istituto LUCE such as Il camminodeglieroi (1936), Il grandeappello (1936), Luciano Serra pilota (1938), Piccolinaufraghi (1939), Trenopopulare (1933), Terra Madre (1931), Sentinelle di bronzo (1937) and Sotto la Croce del Sud (1938) were screened for the Fascist community and their collaborators; out of which Corrado D'Errico's Ilcamminodeglieroi (The Path of the Heroes, 1936) and Guido Brignone's Sotto la crocedel Sud (Under the Southern Cross, 1938), are about the 1936 conquest of Ethiopia (Ben-Ghiat, 1996, pp. 109-144; Monthly Film Bulletin, 1937, p. 264). In most of the films, "Africans... were viewed as unrestrainable, overly sentimental, devoid of logic, prone to criminal behavior, and possessed 
of a dangerous and excessive sexuality" (Ben-Ghiat, 1996, pp. 127-128).

Because of the racial segregation policy of Italian Fascism, movie theatres, except Cinema Ras Hailu were all in all designated to Italians. Even those opportunist Ethiopians and other Africans who collaborated with the Fascist were not allowed to sit mixed with Italians at the cinemas. Early in 1937, black collaborators were admitted to the cinemas, but were allowed to sit only in one designated row. Later, racial legislation prevented Ethiopians from attending the same theatre with Italians. It was such an incident that triggered Abreha Deboch's determination to strike against the Italians and to particularly organize a plot to kill Benito Mussolini's Viceroy Marshal Rudolfo Graziani on 19th February 1937 (Campbell, 2010, pp. 101-197), marking a significant event in the history of Ethiopian national patriotism.

All most all the movies screened were Italian made that portrayed the "civilization and the mighty of Fascist Italy" on one hand, and "backwardness and inferiority of Ethiopians" on the other. The local people were also persuaded by fascists to attend them in open areas in the evenings. Colin (1982, pp. 285-286) describes the emphasis which Fascist Italy gave to cinema for its purpose: "For the ex-journalist Mussolini, the invasion was grand media event, and several talented cameramen were employed to record his imperial triumph". He also notes the reverse by saying "cameras were also at work on the other side, most notably those of a Soviet team." Both they and the Fascists rushed out rival versions, and late in 1936 the Film Society in London showed both alternately, reel by reel. The British indeed have produced over 20 documentaries after the Emperor took refuge in England. Some of the documentaries that the British Pathe (www.britishpathe.com) produced at that period are: Emperor Haile Sellassie Exiled (1935), Abyssinian's Army (1935), Ethiopia (1935), In the War Zone (1935), King of Abyssinia Ethiopia (1935), Italian Guns Ethiopian Solders Ship (1935), The Ethiopian Situation (1935), Abyssinian —Italian Troops (1936), Abyssinian War (1936), Italy (1936), Addis Ababa (1936; 1937), Ethiopia Abyssinia Solders Emperor Haile Sellassie's Tribesmen (1939), Ethiopian Campaign (1941), and The Fall of Addis Ababa (1941). A German newsreel company (UFA) filmed military preparations from the Ethiopian side and a pro-Ethiopia Abyssinia Today was shown in a Berlin theatre in 1935 (Prouty, 1994, pp. 245-248). Prouty further states that "two films came out at the same time"; one "Abyssinia: 1935" produced by Praesens, Zurich may be this one. Its subject was Walter Mittelholzer expedition.

\section{Cinema in Post Liberation Up to the Revolution (1941-1974)}

Reinstatement and expansion of movie theatres. After the expulsion of Fascist Italy from Ethiopian with the collaboration of British army in 1941, Britain attempted to replace Fascist Italy by claiming that Ethiopia was an Occupied Enemy Territory Administration (OETA). "It had in fact replaced the Italians as an occupying power" (Pankhurst, 251, p. 1998). But Emperor Haile Sellassie refused to accept the British move. According to Marcus (1994, p. 153), "The Emperor immediately determined to reduce the potentially dangerous foreign influence by obtaining non-British advisors, by invading London control over Ethiopian's finance and customs, by ending the British military presence... He turned to the United States." Therefore, the role the British played regarding cinema was invisible up until late 1950s.

In the meantime, the ownership of the movie theatres was transferred to expatriates, and the cinemas were also liberated from Italian names. In 1941, Cinema Marconi was renamed Cinema Adwa, and it was run by Robert Djerrahian, "the first of the current theatre managers to get into the business" (Rose, 1969, p. 11). Eda, the former owner of Cinema Peroche (Empero) who retuned back from exile to join the Ethiopian patriots in the struggle against Fascism run Cinema Italia, by naming it Cinema Ethiopia. After a while, Eda for unknown 
reason left for Djibouti and Cinema Ethiopia was transferred to a Djiboutian named Hussein Qasim in 1949. Later on, Hussein Qasim handed over Cinema Ethiopia to his son Nadim Qasim who stayed up until 1968. Cinema Peroche which was named Cinema Empero by Fascists got a new identification as Cinema Empire and was run by Armenians: Blasian, George Mariassis, Arten Avakian, and Poylak Lyon Yazajian (Birihanu Asres, 2013, p. 26) respectively. Later on an Italian who came from Asmara (probably he had been in film business in Addis Ababa during the Italian occupation) replaced them. Cinema Kamboni (Chinque Majo) was given a name Cinema Genet (Asfaw, 2003, p. 165).

The former Fascist officers' club which was reconstructed to be the state owned Hager Fiqir Mahiber/theatre in 1941/42 started movie show in 1959, but could not run for more than a year because the theatre was simultaneously throwing drama and music performances, and film was not preferred to be watched at the place (Tesfaye Mekonen, 2008, p. 12).

Cinema Marconi, the uncompleted Italian movie-theatre, which turned to a waste dump for 15 years, was redesigned by French, Israel, and Austria designers under the supervision of Hennery Schamet. It was marvelously built within four months as per the instruction of the government; and the opening was inaugurated in the presence of Emperor Haile Sellssie in November 1955 as Haile Sellassie $I^{\text {st }}$ Theatre ${ }^{4}$. Both public theatres, designated to produce play and music shows to the public, later on started to include movie exhibition as a regular program.

Cinema Ras Hailu, due to the detention of the owner for collaborating with Fascist Italy, was taken over by Theodor Kakilie (Greek) on a one year contract basis in 1942; but discontinued because of disagreement with inheritors of Ras Hailu. Costa Damas (Armenian) then rented the cinema in 1960 and soon ended up with bankruptcy in 1963. In 1964, George Miriliyas (Greek) transformed the cinema in to a ware house for processing coffee and bean. In 1966, Robert Djerrahian reinstated the cinema and run it, sometimes renting it for boxing contest and Billiard game. A year later, he opened Cinema Addis Alem and cinema Addis Ketema in the vicinity for low income filmgoers with cheaper entrance fee ranging from 25 to 50 cents (Ras Theatre, 1982, pp. 2-36). The two cinemas were extremely hot as they were constructed all-round with corrugated iron and without ventilators. There were few chairs on the first row, and in 1968 the writer of this article had the experience of watching films sitting on the floor amidst a fog of cigarette smoke. Sometimes, it was so difficult to enjoy films independently, because those customers who had seen the movies repeatedly used to narrate loudly to "themselves" the story of the images prior to the appearance of actual episode. The two movie theatres anyhow could not run for more than four years due to box-office failure.

The warm-up of economic development in late 1960s began to expand cinema in major provincial towns. Branches were opened under the auspices of the two public theatres in the northern and eastern parts of Ethiopia. The Haile Sellassie Theatre opened movie theatres in Gander and Bahir Dar when the Hager Fikir opened a cinema in Diredawa. The movie theatres however, could not extend their branches further to other parts of the country due to constraint in human and financial resource. This became a blessing in disguise to let private cinemas emerge in major towns. Nazret, Assella and Awasa (south), Jima and Gore (south-west), Harar

\footnotetext{
${ }^{4}$ Lentakis's observation $(2005,57)$ regarding this theatre seem to be obscure. He writes "it is ironic to enter this National theatre, as they call it now, and see a huge fascist eagle....and in the center of the stage there raises the imperial eagle of Rome, looking ironically down at the audience who certainly do not have any idea of this masterpiece scornfully looking down on them". As a professor of theatre arts, I have been closely associated with the above mentioned theatre for the last 35 years, and I have never seen "in the center of the stage ... the imperial eagle of Rome, looking ironically down at the audience...". Lentak must have been misled by stage scenery constructed for a play that dealt with the theme of Ethio-Fascist struggle.
} 
(east), and Desie (north-east) were left to private business men who by then had learned that cinema could become profitable.

In 1967, three major progresses were registered in Addis Ababa with the establishment of the Addis Ababa Municipality "City Hall" constructed on the 2nd floor of the main building (Addis Report, 1969, p. 16), Drive in Theatre in Kotebie area by Kegnasmach Fasil Shiferaw for those who preferred to watch movies in their car at night, and the opening of the prestigious Cinema Ambassador close to the Haile Sellassie I Theatre by Robert Djerrahian and Tesfaye Qejela. George Dernigulian remembers (EFC, 1988, p. 14) that 1448 Chairs for Cinema Ambassador were imported from France to keep the movie theatre to a professional standard, but the film projectors could not arrive on time from Italy for reason unknown. In order to avoid the delay in the business, the owners of Cinema Ambassador bought an old projector from Cinema Adwa, and additional new one from Italian traders who were conducting an exhibition in Addis Ababa. It is worth noting here that Tesfaye Qejela, next to Ras Hailu is the second Ethiopian who went into film business. Following their footstep, Debebe Eshetu and Wegayehu Nigatu who returned back from Budapest with diploma in theatre arts signed a contract with the Haile SellassieI University to show films at the Creative Arts Center (Interview, Debebe Eshetu, 3 December, 2016). However, the contract was soon cut short by the university due to the intensified students' movement against the monarchic system. The Hager Hiqir theatre had also reinstated a film show in 1968 (Hager Fiqir, 1977, p. 16).

Supply of films. It was not easy for the Addis Ababa movie theatres, to get a good access to feature film distributing companies abroad for more than a decade after liberation. There were attempts to import films from the neighboring Eritrea, which was then a colony of Italy. Esha, a movie about an Eritrean woman was the only film screened for longer period. In the same token, the movie theatres had to screen repeatedly those few American, French, and Indian films. Movie theatre owners had to pay $\$ 5,000$ for "A" class picture, $\$ 3,750$ for "B" and \$ 3,000 for "C" (Addis Reporter, 1969, p. 24).

To the public outside Addis Ababa, the only chance to watch a movie in 60s was limited to some touring documentaries produced by Belgium, Canada, France, United Kingdom, United States of America, and the USSR film companies. About 50 documentary, reportage and newsreel had been produced during the Imperial era by those companies (Solomon Beqele, 1988, p. 6). Most of them were of a propaganda nature in favor of the then government system focusing on the glory of Emperor Haile Sellassie. Some of them were on economic development, Ethiopian patriotism, health Issues such as malaria (Addis Zemen, 3 Ginbot, 1961 [11 May, 1969]). Others were commercials by the Ethiopian Air Lines and Tourism Organization that portrayed various features of Ethiopia. Among those widely projected to the public in provinces were: Ethiopia, Ethiopia-Africa's Ancient Kingdom, Ethiopia-Empire on the Mountain, Ethiopia-The Lion and the Cross, Ethiopia and Eritrea, Ethiopian Mosaic, Italian conquest of Ethiopia, Italy Invades Ethiopia, The Old Africa and the New: Ethiopia and Botswana, Somalia. These films had been considered "relevant to courses of the University and mature presentations suited to senior students" (HSIU, 1971, pp. 1-5). The viewing of such documentaries in the provinces on the other hand had contributed in introducing cinema to public in the country side, and in developing a test for the flavor of the new art as well.

Feature film in Addis Ababa, however, had already been taken as entertainment media in late 60s and early 70s. International film distributors, by then had begun to supply American, Italian, Arab, French, and Indian feature films to the movie theatres on a percentage of the box office basis rather than by charging a fixed 
rate. In 1969, the Ambassador Theatre signed a film distribution agreement with Warner Bros 7 Arts; and after few weeks the 20th Century Fox signed agreement with five theatres: the Ambassador, Emperor Haile Sellassie Theatre, Adwa, Drive-In-Theatre and Cinema Ras, to increase the annual supply to 1969 film. These films had to be approved prior to screening by two groups of Film Review Board that represent Ministry of Information and Ministry of Education. Each group was expected to review about 10 feature films a week under the close supervision of Amare Worku, Deputy Minister of Ministry of Information. In 1968, the Board had reviewed 1,000 films of which 60 were disapproved because of pornography and issues related to matters contrary to Ethiopian culture (Ross, 1969, pp. 10-13). Within a few years, productions of Metro Golden Maier, Paramount Pictures, Universal and Columbia, and 20th Century Fox films became popular particularly among the youth, and it was common to see movie goers every day standing in long cue to secure sits, and narrate to each other the story and actions of films they saw earlier. The Indian film Mother India, however was exceptional in being a box office hit for its sensational musical melodramatic nature that reflected Indians' life which was to some extent similar to that of Ethiopians'. All the cinemas by then had four screening session a day, and it was allowed to see three films with one entrance fee as long as the viewer stay seated in cinema hall. The Hollywood productions were the most attractive exhibition to the youth, and famous stars like Anthony Quinn, Burt Lancaster, Charles Bronson, Charlie Chaplin, Clint Eastwood, Elizabeth Taylor, Frank Sinatra, Gary Cooper, Harry Belafonte, Henry Fonda, John Travolta, John Wien, Kirk Douglas, Madonna, Marlow Brando, Richard Burton, Sean Connery, Shirley McLane, Sydney Poitier, Sophia Loren, and Zewdie Araya (former Miss Ethiopia then residing in Italy), soon became familiar. The urban moviegoers were also influenced by the life styles and personalities of the star-characters, and went to the extent of identifying themselves with the way they dressed, talked, smoked, loved and fought. Fiqiru Kidane (2001, pp. 132-148) remembers that he learnt cigarette smoking by imitating the star of CASA BLANCA; and also recalls that two students - Girma and Renato, who after watching TARZAN, and attempted to live in a jungle coping the style of the character, were apprehended in the Aqaqi forest. America, in such a way has become a dream for many Ethiopian youth.

The contribution of the Ethiopian Television in running films and TV serials to those who could not afforded entrance fee to movie theatres was significant in developing film interest to the wider community in Addis Ababa. Of all television programs, TV serials were so attractive where by household who did not own TV apparatus at home moved to their neighbors' house to attend films together. Other watched the program in bars by paying additional top up price on beverage.

Local film production: The first feature-length film of Sub-Sahara black Africa. The development of cinematic culture and the business prospect attracted the attention of Ethiopians to get organized in order to start film production locally. As a result, a private production company Yehager Filminna Yemastaweqiya Mahiber Yefilm Dirijit [Indigenous Film and Advertising Association's Film Company] was formed by 14 members where Elala Ebsa was elected as an executive director. The first move of the company was to produce a film Salsawi Dawit [King David the III] written by Prime Minister Mekonnen Endalkachew, which was rehearsed for a number of months, but halted due to lack of finance (Aboneh, 2012, p. 4). Elala Ebsa himself wrote the feature film script in Amharic as Hirut Abbatua Mannew [Hirut, Who is her father?] and it was directed by Lombrus Yukaris, another member of the company. The editing was done in Italy with the production of 25 copies. The story of the film centers on the life of a country side girl who is forced by socio 
economic circumstances to engage in urban prostitution. The film was shot in Ethiopia, in which Askale Ameneshewa, Alemayehu Asefa, and Abebech Ejigu performed. The technical film crews nonetheless were Europeans. The production cost was Birr 140,000 [then \$70,000], and Hirut Abbatua Mannew was launched on Friday evening, Nehassie 21, 1957 E.C [August 27, 1965) in the presence of Emperor Haile Sellassie. Papatakis remembers that (Abebe Teshager, 2011, p. 14) the Emperor had walked out amidst the screening with dissatisfaction, commenting on the content of the film "Why a story of prostitute when Ethiopia has a lot more significant history!" In spite of that, the Emperor had received the Askale Ameneshewa in his palace to bestow financial and gold necklace as a gesture of encouragement for best performance regardless of her incapability to read and write (Aboneh, 1994, p. 126). The film run for about four years and it was attended only by about 20,000 viewers facing box-office failure due to the technical standard. The company then was unable to pay back the loan it obtained from Ethiopian Development Bank for the production of the film, and Hirut Abbatua Mannew at last was confiscated by the Bank ${ }^{5}$.

Nevertheless, the production of Hirut Abbatua Mannew, the 35 millimeter black and white feature film with 80 minutes running time has marked a turning point not only in the history of Ethiopian, but also as the first feature-length film made in Sub-Sahara Africa. This point calls for another historiography of African and world cinema, and requires amendment of those scholars who write that La noire de of the Senegalese's Sembene, produced in 1966 (Angela, 1982, p. 107) is the first feature-length film made in Sub-Sahara Africa (Nowell, 1996, p. 668; Petty, 2007, p. 49).

In 1967, the author of Hirut Abbatua Mannew had envisaged to produce the second feature film "King Solomon and the Queen of Sheba with the help of an Israeli film company, but plans have never really gotten beyond the idea stage...movie production in Ethiopia has not been a profitable business" (Ross, 1969, p. 12).

The other important event in the history of the Ethiopian cinema in early 1970s was the return of three Ethiopians: Getachew Desta, Michel Papatakis, and Tafesse Jarra from the Soviet Union with higher education in film Arts. This led to the formation of the 2nd film company "Amare Film Dirijit" (Amare Film Company) by Michel Papatakis and Asrat Getahun where the latter acted as the general manager. With 50,000 Birr loan from a bank, the company produced Guma [ransom for blood guilt], a 35 millimeter colored feature film with 90 minutes running time. The film was written by Michel Papatakis and Yilma Manaye, and directed by Michel Papatakis whose mother heroically resisted Italian fascism as a guerrilla fighter. Guma is the first Amharic colored feature film ever directed by an Ethiopian. The story of the film is based on the Ethiopian customary law, revolving around a character that mistakenly kills his fiend and obliged by the society to pay ransom to the family of the deceased in order to avoid vengeance. The technical aspect of the production was mostly handled by French cinematographers. Michel Papatakis's son Tasso Papatakis, who acquired cinematographic experience in Paris, was the cameraman. The main roles were played by Debebe Eshetu, Kibrom Hagos, Siyum Mulugeta, Negash Abdi, and Selamawit GebreSellassie. Guma was launched on Friday evening, Ginbot 9, 1965 E.C (May 5, 1973) in the presence of Emperor Haile Sellassie I (Ethiopian Herald, May 12, 1973). Guma, however was challenged again with a box office failure, unable to compete with the standard of American and European film productions. As a result, the company could not pay back the loan and the three original copies

\footnotetext{
5 The Ethiopian Development Bank retained Hirut Abbatua Mannew for fifty years and finally presented it as a gift to the Ministry of Culture and Truism. The film was screened as a reception ceremony in 2007 E.C [2015] at the Ethiopian Theatre where it is still reserved.
} 
of the film were confiscated by a bank ${ }^{6}$. Then after, no Ethiopian dared to go into feature film production business for a decade.

On the other hand, film producers from abroad started to focus on Ethiopia locations for shooting international films. The first film was A sailor from Gibraltar, which is based on the story of a sailor from Gibraltar who had a romantic attachment with a French lady and the adventures they were going through. It was directed by British director Tony Richardson and produced by the United Artists Films (1969). It gave an eye opening opportunity for Ethiopian actors, Debebe Eshetu, and Wogayehu to involve in international films with famous actors like Hugh Griffithe, Jean Morroeu.

Unastagioneal'inferno A Season in the Hell, commissioned by the owner of Melotti Beer was produced as a joint venture by French and Italian Film companies, and it was directed by Nello Rissi in 1970. The film is based on true story of Rambo, a French poet who came to Ethiopia as a trader to sale fire arms to Emperor Menelik II. Three Ethiopians: Debebe Eshetu as Emperor Menelik II, Wogayehu Nigatu as Ras Mekonnen, and the notable journalist Eleni Mekuria as a lady had performed in the film. The main Character was casted to Filorina Bolkan, a Brazilian actress because of the difficulty in finding Ethiopian actress who could speak English at that time.

Shaft in Africa (1973/74), the third series was written by Stirling Silliphant, Directed by Jhon Guillerma, and produced by Roger H. Lewis in which Ethiopian casts such as Debebe Eshetu (Wassa), Wogayehu Nigatu (messenger), Zenebech Taddese (bar lady) and Almaz Dejenie (the future wife of Debebe-A passenger) performed along famous actors like Frank Finley (Amafi), Richard Rountree (John Shaft), Vonetta MacGie (Alem), Neda Arneric (Jazar) and Spiro Focas (Sassari). It was premiered at the Haile Sellassie I Theatre in the presence of the Emperor Haile Sellasie I. It is based on the story of human trafficking from Africa to Europe for cheap labor, and it was shot in Ethiopia, France, New York, and Spain. The Emperor and the aristocracy who considered the dressing style of the role of Zenebech as pornographic, however walked out amidst the screening. The Emperor nonetheless received the production crew at his palace (Interview, Debebe Eshetu, 3 December 2016).

From late 1950s to early 1970s, more focus was rather on production of documentaries. The USSR' CSDF produced The Emperor (1959; 1967); Indian and Ethiopian Troops (1955), Duke in Ethiopia (1958), The British Destroyers Visits Ethiopia (1960), Royal Tour of Ethiopia (1965), Christmas in Ethiopian Children of the Emperor (1968) were produced by the British. The Emperor's visits to the USA (1963), and The Emperor's visits to Jamaica (1966) were also documented by western countries (www.nazret.com). Locally, Solomon Beqele who studied film in Germany and France made The Rotten Existence (1968), about corruption; Social Complex (1970), which criticizes the education system in Ethiopia; and Present Situation of African Film (1972), which considers the contradictions presented in African cinema (Angela 1982, 54). To be told a nation and Yetedebeqe Nigus [The Hidden King] were commission by Emperor Haile Sellassie to magnify his positive images against the successive accusations and protests by the Haile Sellassie I university student on the eve of the eruption of the 1974 Ethiopian Revolution.

The bond of cinematic art with socio economic and political reality of Ethiopia was vividly demonstrated by a documentary film that contributed to an end to the monarchical system that existed for about 2,000 years.

\footnotetext{
${ }^{6}$ Guma was handed over to Ethiopian Film Corporation by the Derg Military Government, and after the downfall of the regime, transferred to the possession of the Ministry of Culture and Truism. Few years ago, it was screened for the public at the state owned Ambassador Theatre, and now preserved at the Ethiopian National Archive.
} 
Regarding this, a historian (Bahru, 2007, p. 235) writes:

On the night of 11 September [1974], the ultimate act of vilification was perpetrated as the public was treated to a doctorate edition of a famous film on the 1973 famine produced by Jonathan Dimbleby of Thames Television. A canny collage of royal feast and peasant famine drove home the emperor's alleged callousness to the suffering of his people. The following morning, representatives of the Derg [committee of military] went to the Jubilee palace and read a statement proclaiming his deposition... Thus ended not only one of the longest and most remarkable reigns in Ethiopian history but also a dynasty that traced its origins to King Solomon and Queen Sheba.

The writer of this article also recalls the rage of the Ethiopian people after the film show on the national television, and the consensus to depose the Emperor that had brought significant qualitative change to Ethiopian socio economic and political system.

\section{Conclusion}

Unlike other African countries, the advent and development of cinema in Ethiopia as such is not directly associated with European colonization. The strive by European to win diplomatic relation with Ethiopian monarchies, and the emergence of capitalist system were rather decisive factors for the development of screen media in the Imperial era. Inadequate financial, human, and technical resource, however, could not equate the development of Ethiopian cinema with those Francophone and Anglophone Africa who received financial and technical support from former colonizers to promote film exhibition, distribution and production for their own sake (Angela, 1982, pp. 30-31). Nevertheless, Ethiopia has registered considerable historical development which could have enriched the history of African cinema in particular and world cinema in general. But almost nothing has been said about Ethiopian cinema in articles (Murphy, 2000; Tcheuyap, 2010), books (Grainge, 2007; Nowell, 1996) and encyclopedias (Petty, 2007) written on African and world cinema. Those few who attempt to do so provide erroneous and incomplete account (Angela, 1982, p. 54). This is probably because cinema scholars naively believed that African cinema is merely the legacy of colonialism; or it may be a deliberate act of the hangover of colonialism to distort the history of Ethiopian and African cinema through reduction and omission; or they miss that Ethiopia is part of Africa, or for some other reason that requires further research. This adversely affects not only Ethiopia, but the wholeness of universal truth and knowledge. Therefore, historiography is mandatory to re-consider the African cinema in particular and world cinema in general. The recent attempt by young expatriate and Ethiopian scholars ${ }^{7}$ hopefully will continue to bridge the gap in this regard.

\section{References}

AACCA. (2007). History of cinema in Addis. Addis Ababa in the past and its prospect in the new Millennium. Addis Ababa: Rehobot Printer.

Abebe, T. (2011). New cinema. Addis Ababa: x Printing.

Aboneh, A. (1990). [1998]. Ye Qedamawi Haile Sellassie Teyatere Tarik [History of Haile SellassieI Theatre]. Addis Ababa: paper presented at the 50th anniversary of the Ethiopian National theatre.

\footnotetext{
${ }^{7}$ Four Ethiopians and two expatriate scholars have presented papers on Ethiopian cinema at the 19th International Conference of Ethiopian Studies held in Warsaw (Poland) from 24-28 August 2015. At the closure of the film panel, it was reached at consensus that the scarcity of literature on Ethiopian film is visible. As the result, Alessandro Jedlowski, Mike Thomas and the writer of this article organized themselves as editors to facilitate a publication of anthology on Ethiopian Cinema. The book is now underway for publication which would be the first book on Ethiopian Cinema. Alessandro Jedlowski should be acknowledged for working diligently to the success of the conference, and for taking the lead on the editorial team.
} 
Aboneh, 1994. [2002]. "Ye Ethiopia Tiyatiregnoch Hiyiwot Tarikinna Serawoch" ["The Life and Works of Ethiopian Theatre Artists"]. Addis Ababa: Mimeographed.

Aboneh, A. (2012). Children's theatre in Ethiopia. Aethiopica. International Journal of Ethiopian and Eritrean Studies, 15, 105-117.

Aboneh, A. (2012). The role of women on Ethiopian stage. Journal of African Cultural Studies, 24(1), 1-8.

Adejumobi, S. A. (2007). The history of Ethiopia. USA: Greenwood Press.

Addis Reporter, 1969, Vol. 1, No. 10.

Addis Reporter, 1969, Vol. 1, No. 11.

Addis Reporter, 1969, Vol. 1, No. 12.

Addis Zemen, 3 Ginbot 1961 [11 May 1969].

Asfaw, T. (2003). Ene Mannegn [Who am I?]. Addis Ababa: Chamber Printing.

Bahru, Z. (2007). A history of modern Ethiopia. Addis Ababa: Addis Ababa University Press.

Ben-Ghiat, R. (1996). Envisioning modernity: Desire and discipline in the Italian fascist film. Critical Inquiry, 23(1), 109-144.

Ben-Ghiat, R. (2003). The Italian colonial cinema: Agendas and audiences. Modern Italy, 8(1), 49-63.

Birihanu, A. (2005). [2012]. Ye Tahisasu Girigirena Mezezu [The December Coup d'état and its Repercussion). Addis Ababa: Addis Ababa University Press.

Campbel, I. (2010). The plot to Kill Graziani. Addis Ababa: Addis Ababa University Press.

Debebe, Eshetu, Interview, 3 December 2016, at the Cultural Center, Addis Ababa University.

Dovey, L. (2009). African film and literature. Adapting violence to the screen. New York: Colombia University Press.

EFC. 1988. [1995/96]. ye cinema ajemamer, [The Beginning of Cinema], YayneMisa, [My Lunch], Addis Ababa [Mimeographed].

Ekwuazi, H. (1991). Towards the decolonization of the African film. African Media Review, 5(2), 98.

Ethiopian Herald. August 27, 1965.

Ethiopian Herald. May12, 1973.

Farago, L. (1935). Abyssinia on the Eve. New York: G.P. Putnam's Sons.

Fiqiru Kidanie. (2001). [2009]. Ye PiasaLij (The Piassa Boy). Addis Ababa: Fareast Trading.

Gebru, T. (2009). The Ethiopian revolution. London: Yale University Press.

Gerard, A. (1971). Amharic literature. In ID., Four African literatures: Xhosa, Zoto Zulu, Amharic (pp. 271-376). Berkeley: University of California Press.

Getahun, Solomon H. (2007). The history of Ethiopian immigrants and refugees in America 1900-2000. New York: LFB .

Grainge, P., Jancovich, M., \& Monteith, S. (2007). Film histories. Edinburgh: Edinburgh University.

Lentakis, M. (2005). Ethiopia: A view from within. London: Janus Publishing Company.

Hager Fiqir Theatre 1998. Addis Ababa: Nigidmatemiya.

HSIU. 1971. HaileSellassie I University. Addis Ababa: BS Printer.

http:/www.britishpathe.com

http:/www.nazret.com

Marcus, H. G. (1994). A history of Ethiopia. Berkeley: University of California Press.

Martin, A. (1982). Africa films. London: BFI Publishing.

Monthly Film Bulletin 4, 1937.

Murphy, D. (2000). African filming Africa: questioning theories of an authentic African Cinema. Journal of African Cultural Studies, 13(2), 239-249.

Murra, C. (1982). Fascist invasion of film. Journal of African History, 23(02), 285-286.

Nowell, G. (1997). The Oxford history of world cinema. Oxford: Oxford University Press.

Pankhurst, R. (1968). Economic history of Ethiopia. Addis Ababa: Haile Sellassie University Press.

Pankhurst, R. (1998). The Ethiopians. Oxford: Blackwell Publisher.

Pariset, D. (1937). Al tempo di Menelik. Roma: Societa An Editrice Valentino Bompiani \& c.

Pawlos, N. (1984) [1992]. Atse Menelik [Emperor Menelik]. Addis Ababa: Kuraz publisher.

Petty, S. (2007). Africa south of the Sahara. Schimer Encyclopedia of film. New York: Thomson Gale.

Prouty, C. (1994). Documenting Ethiopia. Proceeding of the Eleventh International Conference of Ethiopia Studies. Addis Ababa: Addis Ababa University Press.

Prouty, C. (1996). An anthology of films in Ethiopia and Eriterea. Addis Ababa: IES. 
Ras Theatre. (1982). Ras theatre annual report. Addis Ababa: Mimeographed.

Ross, J. (1969). The Addis movie scene. Addis Reporter Weekly Magazine, 1(13).

Rouch, J. (1962). The awakening African cinema. UNESCO Courier, March, 15th Year Paris.

Solomon, B. (1988). [1995/96]. ye cinema Metoamtinna Africa [Centenary of Cinema And Africa].Yayne Misa [Lunch of my Eyes]. Addis Ababa: Mimeographed.

Tcheuyap, A. (2010). Comedy of power, power of comedy: Strategic transformations in African cinemas. Journal of African Cultural Studies, 22(1), 25-40.

Tesfaye, L. (1985 E.C). [1992/93]. Erkata [Satisfaction]. Addis Ababa: Mimeographed.

Tesfaye, M. (2008). Film. Ye Addis Ababa tiyaterena Bahil Adarasharbagnaamte [The Addis Ababa Theatre and Culture Hall-40th Year). Addis Ababa: Samket Printers. 